\title{
Entrepreneurship Interest Measurement Model For Degree Candidates As Evaluation Basis For Entrepreneurship-Oriented Learning System
}

\author{
Yarnest $^{1)}$, Abdul Manap Wardoyo ${ }^{2)}$ \\ ${ }^{1,2)}$ Dosen Fakultas Ekonomi dan Bisnis, Universitas Merdeka Malang, Indonesia
}

\begin{abstract}
This study aims at finding out degree candidates' level of interest in entrepreneurship, what major factors lead to the emersion of such interest, and which entrepreneurship model contributes the most in the emersion of such interest. Entrepreneuship interest variable factors is measured from preferential, intrinsic and extrinsic factors on the emersion of Interest in Entrepreneurship. This study uses the survey and questioner method, with factor and descriptive analysis technique as basis for model design. This study analyses and identifies dominant factors influencing the building of interest in entrepreneurship of degree candidates. Data of 143 students acquiring the course in entrepreneurship were processed using SEM software. The results of the study shows that the level of interest of degree candidates is very high (87,4\%) with intrinsic as the major and dominant factor and extrinsic factor having significant infuence toward the emersion of interest in entrepreneurship for degree candidates. The entrepreneurship model with the largest contribution for the emersion of interest is the intrinsic factor.
\end{abstract}

Keywords: Learning System, Entrepreneurship, Degree Candidates

\section{Introduction}

As a system, education cannot be separated from the larger extent outside education itself. Education has a functional link with other sectors in life outside the education system. Realizing that education possesses intrinsic function, education system cannot be separated from the current and future challenges including education within the university. Based on the aforementioned, challenges faced by universities are not solely internal factors but also from outside the education system. Thus external challenges are the major aspirations in undergoing internal changes or reforms, including reforms in the content of curriculum offered.

The discussion on job opportunities for degree graduates cannot be separated from the situation of existing economic and manpower issues. The extent of layoffs and unemployments is a serious challenge for degree candidates. Furthermore, data on manpower issues in Indonesia again bring out a significant problem, the large number of edified unemployment. (Republika.co.id, 2012).

The government's effort to employ civil servants is certainly not sufficient. Providing job opportunities for university graduates is not a simple task. On the other hand, the level of interest in entrepreneurship in part of university graduates is very low. In general, they are prepared to be job seekers instead of job creators. Based on the data from Directorate General Youth and Non-Formal Education of the National Education Department, from 75.3 million Indonesian youth, only $6.6 \%$ are graduates. From the latter number $82 \%$ work in government or private offices, while ony $18 \%$ are self-employed or working as entrepreneurs, whereas the greater the number of graduates working as entrepreneurs the faster the economic recovery.

Entrepreneurship governs the economic progress of a nation. Singapore, for instance, became a developed country through entrepreneurship principles. Their government urges university graduates to become creative entrepreneurs and build formidable smale medium scale businesses. This has led to the establishment of a world-class IT industry initially initiated by young entreprenuers. The same token was also applied by the United States, Taiwan, South Korea, countries sensitive to the establishment of entrepreneurs (Longenecker,2000).

Zimmerer, 2002 under Suharti (2011:125), the growth factor of entrepreneurship in a country depends on the role of universities through the application of curriculum content on entrepreneurship. The role of universities in this endeavor is to educate and develop entrepreneurship capabilities to degree candidates and the encouragement to the students to path entrepreneurship as their career. Universities prepare students not only to be interested, but also to become capable and quality young entrepreneurs eager to compete so that there would be more graduates able to restrain the rate of unemployment and to augment job opportunities. Yohnson, 2003, $\mathrm{Wu} \& \mathrm{Wu}, 2008$ said that universities need to apply concrete entrepreneurship learning pattern based on emphirical feedbacks to equip degree graduates with sufficient knowledge to drive their courage to be selfemployed. The question now is whether universities can give birth to or generate young entrepreneurs. Observing the students' entrepreneurship career selection can give an initial picture of degree candidates' 
interest toward becoming young entreprenuers. They are interested because they are capable. This is expected to be the basis of evaluation in the role of preparing and motivating universities on entrepreneurship discipline toward their students in the future in respect to the government's program, DEPDIKNAS (National Education Department) in this matter. It is with the above reasons that the Measurement of Entrepreneurship Interest for Degree Candidates as Basis for Evaluation in Entrepreneurship-Oriented Learning study is conducted, considering that the impact of this study can be used to evaluate the role of lecturers/universities to prepare and motivate the option for entrepreneurship career, to create quality, independent individuals, capable of adapting to existing opportunities, mitigate edified unemployment and declining trust toward education, and to escalate economic growth to a more promising direction.

The purpose of the study: (1). to identify the extent of interest level of degree candidates in Malang City to be entrepreneurs, (2). to identify the main factors leading to the emersion of such interest in entrepreneurship, (3). to identify the most contributing entrepreneurship model for the building of interest in entrepreneurship.

\section{Entrepreneurship Concepts}

\section{Critical Review}

Entrepreneurship originates from entrepreneur (France), or wiraswasta/wirausaha (Indonesia). In terminological terms, it means between takers or go between. Etimologically, the understanding of entrepreneur develops over time. Entrepreneurship can also be identified as the ability to see and asses business opportunities, collect resources required to profit and to take appropriate actions to ensure success (Merediht, 2000). According to Hasun (2004), entrepreneurship is a creative course of action adding value to something that is non-existence. While Kao (2005) mentioned entrpreneurship as a process of creating something new and make something distinguished from what is already in existence (innovation), in order to accomplish individual welfare and add value to the community. Entrepreneurship is also identified as somebody capable of turning ideas into reality (Hisrich, 1992). In general it is said that entrepreneurs have the potential to achieve something. They have great motivation to progress and achieve something, capable of helping themselves and overcome problems in life no matter the condition. Quality entrepreneurs must have the strength as their asset, and to earn such they have to study in order to become quality human resources.

\section{Factors Influencing Interest in Entrepreneurship}

According to Suryana (2000) entrepreneurship is the capability to take the liberty in meeting and solving life necessities and problems, advancing or creating new business using own resources or strength. Entrepreneurship is a physical sympthom to focus and commit oneself to entrepreneurship contentedly as it brings benefit for him or her. Interest is closely associated with consideration, and as such, the factors involved are disposition, mood or feeling, environment, stimulus and will (Suryana, 2000). According to Owen (2004) environmental factors influencing interest include family, school and the community. From the two assessments above it can be concluded in general that factors influencing interest can be categorized into intrinsic and extrinsic factors. (Suharti dan Hani, 2011) concluded in their study that parent's work/job, socio-demographic factor as entrepreneurs bear significant influence toward the student's intention/motive in entrepreneurship, while gender and study program do not. On the other hand, behavioral factors, namely authority, economic challenge, self realization, security and workload, along with academic and social support contextual factors have evidently been positively and significantly proven as influential toward the students' interest in entrepreneurship. Meanwhile, Lestari and Trisnadi's (2012) study concluded that education in entrepreneurship bears significant influence toward students' interest in entrepreneurship. Education in entrepreneurship is executed through learning process to change the students' behavior and thinking pattern in selecting entrepreneurship as their career.

\section{Methods}

\section{Population and Sample}

The population in this study were students already passing entrepreneurship course at the S1 level. Samples in this study were designated using guidelines provided by Arikanto. In view of the number of population that could reach thousands of graduates, samples were taken $10-15 \%$ or 143 respondents, using the proportional random sampling method.

\section{Study Variables, Operational Definitions of Variable and Measurement}

This study uses two variables namely interest in entrepreneurship and entreprenership-oriented learning system. Interest in entrepreneurship is defined as the interest, consideration and readiness of degree candidates to become entrepreneurs. Meanwhile, indicators and items of variables are as shown on Table 1. For X1 
measurement uses Graphic Rating Scales, while X2 uses Likert modified scale with 4 scales: Strongly Agree, Agree, Disagree, Strongly Disagree.

Table 1. Entrepreneurship Variables, Indicators and Items

\begin{tabular}{|c|c|c|}
\hline Variable & Indicator & Item \\
\hline \multirow{9}{*}{$\begin{array}{l}\text { (Y) Interest in } \\
\text { Entrepreneurship Owen } \\
(2004)\end{array}$} & $\begin{array}{l}\text { Preference of interest toward } \\
\text { entrepreneurship }\end{array}$ & Level of interest in entrepreneurship \\
\hline & $\begin{array}{l}\text { Intrinsic factors leading to } \\
\text { interest in entrepreneurship }\end{array}$ & \begin{tabular}{|l|} 
ontentment \\
alent in subject \\
elf esteem \\
hcome potential \\
\end{tabular} \\
\hline & Extrinsic factors leading to & arents' influence \\
\hline & interest in entrepreneurship & ocial Status \\
\hline & & vailability of job opportunity \\
\hline & & svailability of local opportunity \\
\hline & & Influence of entrepreneurship lecturer \\
\hline & & $\begin{array}{l}\text { Influence of entrepreneurship activity programmed by } \\
\text { universities }\end{array}$ \\
\hline & & eer influence \\
\hline
\end{tabular}

Meanwhile, variables for entrepreneurship-oriented learning system is defined as lecturing activities, apprenticeship, work/field practice, mentoring or training in programmed entrepreneurship activities which course had been attended by degree candidates.

\section{Data Analaysis Technique}

To asses and describe the interest in entrepreneurship of degree candidates in Malang, this study uses the descriptive analysis and structural equation modeling (SEM) data analaysis technique.

\section{Data Normality Evaluation}

\section{Results}

The data normality results proved that respective critical ratio skewness and critical ratio multivariate values are still within the $-2,58$ and 2,58 range meaning that there is no problem in terms of data normality meaning that observed data is normaly distributed.

\section{Evaluation on Out-lier}

Study results show that there is not a single Mahalanobis distance squared value of the respective observation data exceeding the Chie square table $(40,79)$ value. As such, observation data collected is freed from outlier issues.

\section{Multicollinearity Evaluation}

The results of correlation matrix output from scalable/measured variables shows that there is not one single value exceeding 0,9 . Such results show that there is no multicollearity issues.

\section{Equation Model Feasibility Test}

The overall model feasibility test uses Structural Equation Modelling (SEM) analysis, which simultaneously is used to analyse the hypothesis proposed. Based on the AMOS 18 statistic computerized calculation program, the overall model sult is as presented on the illustration below: 


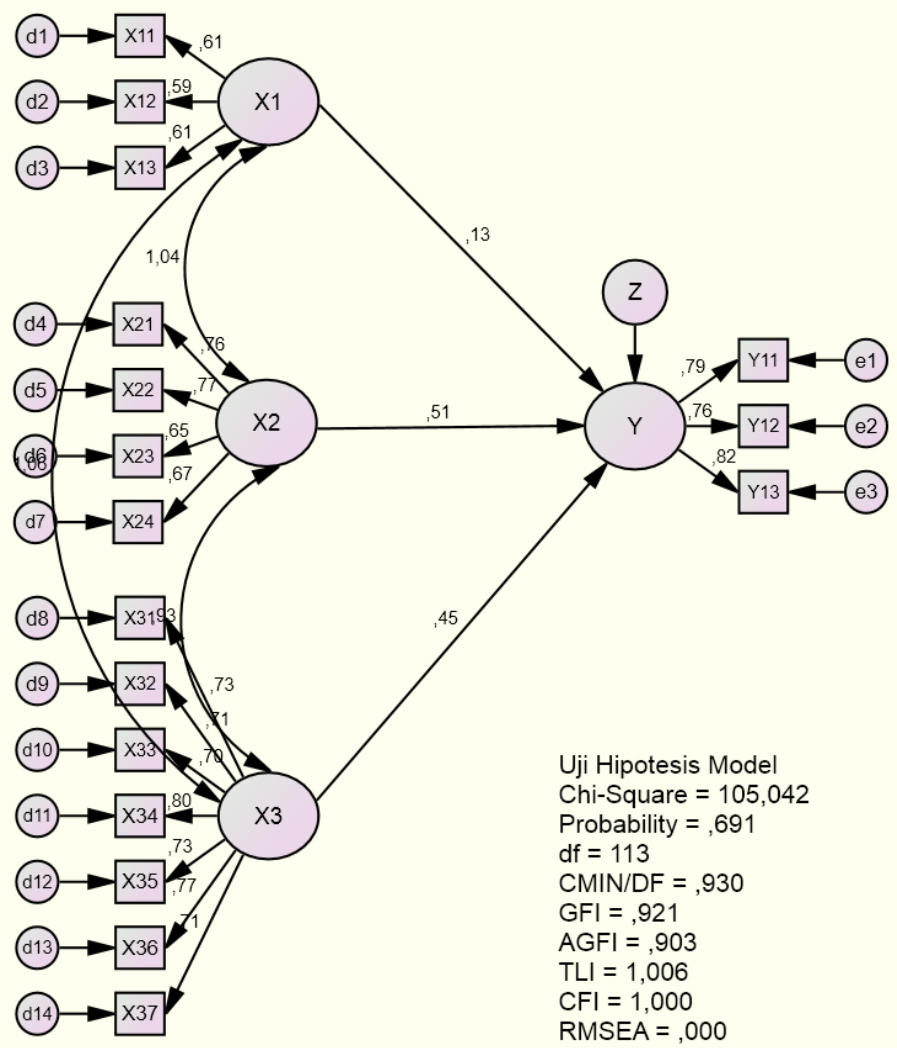

Illustration 1

Structural Equation Model (SEM) Analysis Results

Remarks:

$\mathrm{X}_{1}$ : Preference of interest toward entrepreneurship

$\mathrm{X}_{2}$ : Intrinsic factors leading to interest toward entrepreneurship

$\mathrm{X}_{3}$ : Extrinsic factor leading to interest toward entrepreneurship

$\mathrm{Y}:$ Interest toward entreprensurship

The following table is the summary of the results of structural equation modelling analysis:

Table 2. Model Feasibility Testing Results

\begin{tabular}{|l|c|c|c|}
\hline \multicolumn{1}{|c|}{ Goodness of fit indices } & Cut-off value & Result & Remarks \\
\hline Chi-square (df=113) & 124,34 & 105,042 & Good \\
\hline Probability Chi-Square & $\geq 0,05$ & 0,691 & Good \\
\hline CMIN/DF & $\leq 2,00$ & 0,930 & Good \\
\hline RMSEA & $\leq 0,08$ & 0,000 & Good \\
\hline GFI & $\geq 0,90$ & 0,921 & Good \\
\hline AGFI & $\geq 0,90$ & 0,903 & Good \\
\hline TLI & $\geq 0,95$ & 1,006 & Good \\
\hline CFI & $\geq 0,95$ & 1,000 & Good \\
\hline
\end{tabular}

Source: processed primary data, 2016.

The analysis of processed data shows that all construct/hypotheses used to establish the study in the SEM full model analysis meet the designated goodness of fit criteria. The goodness of fit indicator showing fit condition is bring about by the 105,042 chi-square number which suffices the probability value of 0,691 or above 0.05 . The said value/number shows that there is no difference between the estimated sample covarian matrix and population covarian matrix. Other goodness fit indicators also show good condition. Therefore, the study model can be used as study analysis tool. 
Influence of Preference, Intrinsic and Extrinsic Factors against Interest toward Entrepreneurship

Results of SEM analysis as outlined on the table below:

Table 3. Influence of interest preference against entrepreneurship (X1), Intrinsic factor leading to entrepreneurship emersion (X2), Extrinsic factors leading to entrepreneurship emersion (X3) toward

\begin{tabular}{|c|c|c|c|c|c|c|c|}
\hline \multicolumn{3}{|c|}{ Variable } & $\begin{array}{c}\text { Standardized Regression } \\
\text { Weight }\end{array}$ & Estimate & S.E. & C.R. & P \\
\hline $\mathrm{X} 1$ & $\rightarrow$ & $\mathrm{Y}$ & 0,129 & 0,167 & 0,200 & 0,838 & 0,402 \\
\hline $\mathrm{X} 2$ & $\rightarrow$ & $\mathrm{Y}$ & 0,513 & 0,570 & 0,204 & 2,801 & 0,005 \\
\hline $\mathrm{X} 3$ & $\rightarrow$ & $\mathrm{Y}$ & 0,452 & 0,477 & 0,217 & 2,195 & 0,028 \\
\hline
\end{tabular}

Source: Processed primary data, 2016.

Test results indicate that interest preference toward entrepreneurship (X1) do not influence the emersion of interest toward entrpreneurship with a probability of 0,402 (higher than 0.05 ). The direction and extent of standardized direct effect coeficient is 0,129 and to test its significance the value $p>0,05$ is applied. Intrinsic factor leading to entrepreneurship interest has a significant influence against entrepreneurship interest with a probability value of 0,005 (less than 0,05 ). The direction and extent of standardized direct effect coeficient is 0,005 (less than $(0,05)$ and to test its significance the value of $p<0,05$ is applied. Extrinsic factor leading to interest in entrepreneurship influences entrepreneurship interest significantly with a probability of 0,028 (less than 0,05). The direction and extent of stnadardized direct effect coefficient is 0,452 and to test its significance the value of $\mathrm{p}<0.05$ is applied.

\section{Discussion}

Results of analysis show that preference does not influence interest toward entrepreneurship. This indicates that high interest preference without managerial capabilities, insufficient experience in operations and production, weakness in financial control, inadequate location, reluctance in business, incapabilities in entrepreneurship transitions serve as the culprits of entrepreneurship failures.

Intrinsic factor influences interest toward entrepreneurship. This is underlind by the responses inclining to agree with income and self esteem potential indicators. However, contentment and talent toward subject are factors mostly perceived by respondents. One who believes in capability and business concepts can accomplish what has been initiated. One of the entrepreneurs successs factor is imagination and supplementary plans. They have the ability to see opportunites others can't. Entrepreneurs must know what consumers demand, even before they realize that they want them, and as soon as possible. Although many believe that entreprenuers are motivatd by income, there are other more important factors, such as the need to accomplish maximum achievement as shown above. The desire to be independent is more important compared to the motivation for income itself. In the outset, entrepreneurs initiate their businesses because they do not want to work for someone else (boss). Their rationales are: 1) to use their own skills and capabilities, 2) control upon their own lives, 3) the desire to endow something to the family, 4) the will to face challenges, 4) to have the freedom to live their own lives.

As phrased by Kuncara (2008:1) that entrepreneurship is driven by internal factors, namely personal prowess on how to manage oneself. Personal prowess consists of 5 important elements: 1) self consciousness. This refers to the capability to know and control own emotions and effects, own strengths and limitations, and conviction on self esteem or confidence. (2) self control. This refers to the control of detrimental emotions and compulsions, maintaining honesty and integrity norms, accountability of own performance, flexibility in facing changes, and receptive or openess for suggestions. (3) motivation. This relates to the drive to succeed or to become better, commitment, initiative to use opportunities, and optimism in facing obstacles and failures.

Extrinsic factor infuences interest toward entrepreneurship. This is underlined by responses tending to agree with indicators of parents' influence, social status, availability of local opportunities, peer influence and entrepreneurship activities programmed by universities. However, indicator on the availability of job opportunity is the one most perceived by repondents. Therefore, to become an entrepreneur requires the support of others related to the business being managed. An entrepreneur must be able to weather existing challenges and risks. Risk is used as trigger to progress, as through risks, an entrepreneur will make progress. According to Murphy and Peek which book was translated by Bukhari Alam, there are eight steps that cover the success of an entrepreneur in developing its business, namely: a) hard work, a requisite for an entrepreneur to succeed. Every successful entrepreneur works really hard in his or her business, b) cooperation with others. This can be accomplished in social environment as the first step in developing business. An entrepreneur must be generous, sociable, cordial and well-liked by the community and avoid actions that may disadvantage others, c). good appearance, emphazised in honest and disciplined behaviour, d). confidence, an entrepreneur must have self confidence, confidence to progress based on perseverance and patience. e). decisive, an entrepreneur must be able to make decision. When faced with complicated alternatives, use sound judgement, not hesitant in making 
good decision based on confidence. f). willingness to learn. By generating knowledge, especially in business, an entrepreneur is expected to be able to support his or her capability and progress in business, g). ambition to progress. Without strong ambition, an entrepreneur cannot achieve success. Strong ambition must be balanced with hard work and good self discipline, h). good communication skill. An entrepreneur must be able to attract others through good words, politeness, and self confidence. This will impress others and bring trust to what is being said.

Successful entreprenuers are also successful leaders. Reffered to as leaders, because they have to find opportunities, through projects, gathering resources (materials, technology, human and capital) required to execute projects, designate goals, either for themselves or for others, lead and guide others to achieve goals. Effective leaders will always find better ways or methods. Effective leaders believe in sustainable growth, increasing efficiency and continuous success from his or her business.

According to Kuncara (2008:1), external factor is the driver of entrepreneurship. External factor is a social skill on how to manage relationships. Social skill consists of two important elements, namely: 1) empathy. This relates to the ability to understand others, others' perspectives, and concern toward others' interests. It is also the ability to anticipate, identify, and the effort to meet consumers' demand. Overcoming diversity in building social relations, developing others, and the ability to read emotional flows of a group and its association with power/regime involved therein. (2) Social skills. Included herein are tactics to convince others (persuasion), communicating clearly and convincingly, generating inspiration and guide groups, initiating and managing changes, negotiating and solving disagreements, cooperating for common goals, and creating group synergy in striving for common goals.

The finding of this study is that interest in entrepreneurship for degree candidates is influenced by intrinsic and extrinsic factors as presented on Illustration 2.

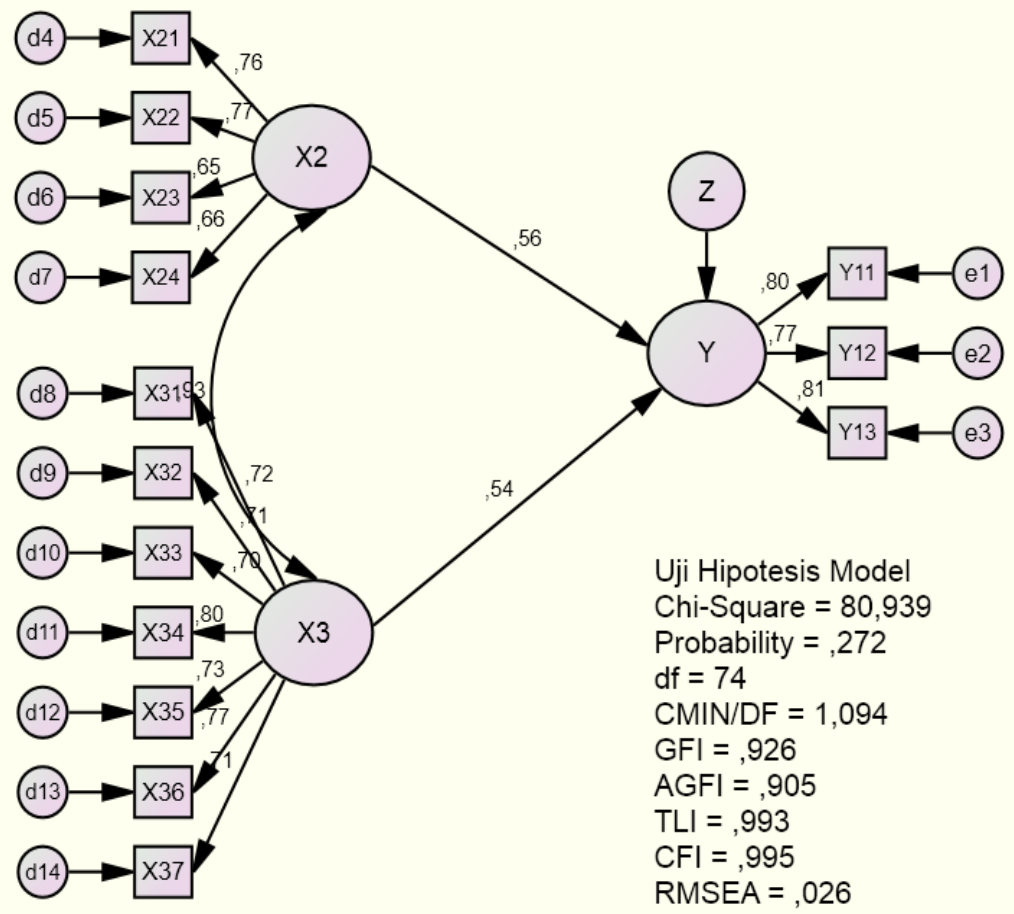

Illustration 2

Study Result Finding Model

Illustration 2 indicates that intrinsic factor is more dominant as compared to extrinsic factor. Intrinsic factor is build from contentment, talent toward subject, self esteem and potential. Intrinsic factor with the highest influence toward interest in entrepreneurship is talent toward subject. While extrinsic factor is build from influence of parents, social status, and availability of job opportunity, availability of local opportunity, entrepreneurship activities programmed by university and peer influence. Extrinsic factor with the highest influence is entrepreneurship activities programmed by university. 


\section{Conclusion}

Result of analysis shows that the level of interest of degree candidates in Malang to become entrepreneurs and preference of interest toward entrepreneurship are not influential toward the interest in entrepreneurship. Intrinsic factor trigerring the interest toward entrepreneurship has significant influence againt the interest in entrepreneurship. Extrinsic factor triggering the interest toward entrepreneurship has significant influence toward the interest in entrepreneurship. This suggests that the factor influencing the interest of students toward entrepreneurship - internal factor- starts from contentment, talent toward subject, self esteem and income potential, while external factor starts from parents' influence, social status, availability of job opportunities, influence of lecturers in entrereneurship course, entrepreneurship activities programmed by the university, and peer influence.

\section{Suggestions}

To conduct not yearly but three times yearly routine activities in equipping students attending entrepeneurship classes with entrepreneurship activities for the students to have deeper insights on the business world and to be able to share their experience with their seniors as mentors/presenters in their entrepreneurship activities program. Collaboration with successful external business players to create a sharing and mentoring forum for students attending entrepreneurship program to enhance their interest and to share their experiences in doing business.

\section{References}

[1]. Anonim. Republika.co.id, 2012. Jakarta. Wednesday, 12 September 2012, 16:41

[2]. Arikunto, Suharsimi. 1998. Prosedur Penelitian Suatu Pendekatan Praktek (Edisi Revisi IV). Jakarta: PT Rineka Cipta.

[3]. _ 2000. Prosedur Penelitian Suatu Pendekatan Praktek. (Edisi Revisi V) Jakarta: PT Rineka Cipta.

[4]. Hall, Craig, The Responsible Entrepreneur : How to Make Money and Make a Difference, (USA : Career Press, 2001)

[5]. Husnan, Zafir .2004. Menjadi Usahawan : Panduan menubuhkan dan menguruskan perusahaan secara profesional, (Malaysia : Malindo Printers Sdn)

[6]. Hisrich dan Michael P. Peters, et.al. 1992. Entrepreneurship: Starting, Developing, and Managing a New Enterprise, Tokyo: Richard D. Irwin.

[7]. http://www. Ummigroup.Co.Id. Menumbuhkan Kewirausahaan Sejak Dini,2009

[8]. $\quad$ http://www. Ketenagakerjaan.yahoo.com.download 2009.

[9]. [9] Ibrahim, A. Bakr, \& Williard H. Ellis, A. Bakr. 2001. Entrepreneruship and Small Business Management, Iowa: Kendall/Hunt Publishing Company

[10]. Kao, John J. 2005. The Entrepreneurial Organization, Prentice-Hall International, Inc.

[11]. Kristianse, Stein.2003. Small Scale Buisnes in Rural Java: Involutioner Innovation, in The Journal of Entrepreneurship, Vol, 12. Sage Publication, New Delhi

[12]. Lestari, Retno Budi dan Wijaya, Trisnadi, 2012. Pengaruh Pendidikan Kewirausahaan Terhadap Minat Berwirausaha mahasiswa di STIEMDP,STMIK, danSTIE MUSI. Jurnal Forum Bisnis dan Kewirausahaan Vol.1 No. 2. Maret 2012: 112-119. Jurnal Ilmiah STIE MDP

[13]. Longenecker, Justin G, et. al.2000. Small Business Management an Entrepreneurial Emphasis. United State: South-Western College Publishing.

[14]. Meredith et. al., Geoffrey G. 2000. Kewirausahaan: Teori dan Praktek, Andre Asparsayogi (pentjh.), PPM,Jakarta

[15]. Owens, Jonathan. 2004. An Evaluation of Organisational Groundwork and Learning Objectives for New Product Development, in Journal of Enterprising Culture, Vol. 12. Singapore

[16]. Setiawan,Ivan dan Ghozali,2006. Akuntansi Keperilakuan.Konsep dan Kajian Empiris perilaku Akuntan. Universitas Diponegoro, Semarang.

[17]. Suharti, Lieli dan Hani Sirine, 2011. Faktor-faktor yang Berpengaruh TerhadapNiat Kewirauasahaan (Entrepreneurial Intention), Jurnal Manajemen dan Kewirausahaan, Vol.13. No.2. September 2011: 124-134. Universitas Kristen Setya Wacana. Salatiga Solo.

[18]. Sukardi, Dewa Ketut. 1998. Pendidikan Konseling dalam Bimbingan Karir. Jakarta: Ghalia Indonesia.

[19]. Suryana. 2000. Kewirausahaan. Jakarta: Salemba Empat.

[20]. ------, Rural small-scale industries in a developing region : sign of poverty or progress ? in An International Journal Entrepreneurship and Regional Development, Volume 6, 1996 Taylor and Francis, Dublin, Ireland

[21]. Vinturella, John. B., Entrepreneurship: Concepts and Issues. Prentice Hall Inc, 1999, New Jersey The Entrepreneur's Field Book.

[22]. Wu, S \& Wu, L. 2008.The Impact of Higher Education on Entreoreneural Intention of University Student in China. Journal of Small Business and Enterprise Development, 15(4):752-774.

[23]. Yarnest. Optimalization on Natural Resources And Cultural Heritage As Ceramic Industry Business Development Strategy. IOSR Journal of business and Management.Vol.17 Issu 11.Version-III (Nov.2015)

[24]. Yohnson. 2003. Peranan Universitas dalam Memotivasi Sarjana Menjadi Young Entrepreneurs. Jurnal Manajemen dan Kewirausahaan, 5(2): 97-111. 